\title{
3. Making reforms sustainable: lessons from the American policy reform experience
}

\author{
Eric M. Patashnik
}

This chapter concerns my most recent research on making policy reforms sustainable in the US policy context, and will synthesise and build upon themes developed in my 2008 book, Reforms at Risk: What happens after major policy changes are enacted. What follows has four interconnected parts. First, I explore why it is important to strive for sustainable reforms. Second, I consider the puzzle of reform: why some reforms 'stick' and why others do not. I do this by introducing several concepts and by tapping into several case studies of policy reform in the United States. Third, with several cases in hand, I will identify the factors that tend to be associated with sustainable reforms. I will conclude by exploring the implications for increasing the prospects for success.

\section{The importance of sustainable reforms}

Policy reforms are often adopted with great fanfare in the legislature and among the media. It is a tremendous achievement when the political system is able to muster the will and ability to tackle an important problem and to reform it. But the struggle to recast governance does not end at the moment of enactment. The politicians who spearheaded a reform effort can change their minds about their policy goals. They might decide to do something in one year, but in five years they have a different point of view. There are always pressing priorities for any government. New problems emerge, and the one that they were so focused on in the past might no longer be as pressing; they might lose interest in an issue altogether. Alternatively, the politicians who once championed a certain reform might be replaced by other officeholders, or by new coalitions that have different values and priorities.

Policy reform usually breeds enemies. Often, a reform will tackle the privileges of some narrow constituencies, some special interest whose benefits are inimical to the larger common good. Those special interests might be the losers at the moment of reform enactment, but they do not necessarily wither or disappear. They might lose one battle, but they will be back to fight another day. For these reasons, reform must be seen as a dynamic process in which ongoing consolidation can be more difficult than winning adoption of the reform in the first place. To draw an analogy from everyday life, losing weight might be hard, but the real challenge is keeping the weight off. 
But why should officeholders and citizens care whether reforms stick? When reforms unravel or collapse after enactment, several negative things can happen. First, the policy gains can be squandered; the very achievements that were fought for and accomplished in the process of enactment can be lost. Second, when a reform unravels or erodes, it undermines the ability to plan for the future. Citizens need to know what they can expect from government. They need to adapt their own private lives to the expectations of the benefit flows that will be forthcoming. When reforms unravel, people lose their ability to make long-term commitments. And finally, when policy makers work hard to reform a policy area only to see the reform collapse after enactment, it increases public cynicism about government's ability to actually solve problems. This is detrimental to building support for improved governance.

Consequently, for policy makers who care about solving problems for the public good rather than being involved in symbolic efforts that look good but do not actually achieve anything, it is crucial to consider what happens after reforms are adopted. This means policy advocates should integrate a concern for reform sustainability into their policy designs and implementation strategies. From the outset, they should consider the question: can this new policy reform sustain itself over time? It also means policy evaluators should emphasise sustainability as a criterion in assessing reform proposals prospectively. Similarly, the prospects for reform sustaining itself should be considered when gauging governmental performance. Citizens should ask themselves: this reform is working today, but will it work tomorrow?

Reforms endure not because they are frozen in time or place or because their background conditions do not change, but rather because they reconfigure the political dynamic. It is not the case that we build an edifice of reform that is so solid it cannot actually be moved. Instead, reforms must reflect the everchanging nature of politics, where new issues are constantly emerging and new coalitions are continually forming. We need to stay afloat even in choppy weather.

Sustainable reforms achieve three key outcomes. First, they remake political institutions - the rules and sets of authority relationships by which we are governed. In this way they are not simply changing public-policy outputs; they are remaking governance. Second, sustainable reforms upset coalitional alignments and cause constituency groups to become vested in the new status quo. This is a political process that reallocates power, authority and standing to groups and interests that were previously weak. We reform government in order to empower people who were previously disenfranchised. Finally, sustainable reforms recast ideas and alter the menu of policy solutions. 
It is thus crucial for policy makers to consider the capacity of a reform to maintain its structural integrity and to use its core principles to guide its course amid inevitable pressures for change. What such sustainability entails is much more than simply assembling a new policy machine and making it run, but rather remaking the political context in which subsequent policy decisions are made. In other words, a sustainable reform should change the way politics plays out - changing the debate, causing new arguments to emerge and rendering old ones that were previously persuasive irrelevant or unconvincing. This is a very powerful achievement, and it is not surprising then that many reforms lack the capacity to do these things.

\section{The unravelling of tax reform}

To illustrate some of these concepts, consider the unravelling of one very important landmark reform in the United States: the Tax Reform Act of 1986. This was an effort at the federal level to broaden the tax base in order to eliminate many special tax loopholes that favoured various narrow constituency interests - the oil industry and realtors, for example - but the result was a tax code that was so filled with special tax loopholes that overall rates for ordinary Americans had to be much higher than they otherwise would if the tax base had been broader and free of exemptions.

The initial reform was a tremendous achievement. It collapsed 14 tax brackets into two, eliminated approximately US\$500 billion in tax breaks for various narrow interests, and shut down tax shelters for high-income individuals. The reform was also an outstanding example of bipartisanship, with President Ronald Reagan calling it 'the best job creation bill ever to come out of Congress in the United States' (Sydney Morning Herald 1986), and the more liberal New York Times editorialising: 'At last. It's a day to stop and take unashamed satisfaction on the triumph of the whole over the parts.' (New York Times 1986).

And yet, while the Tax Reform Act has never actually been repealed, the whole reform project has collapsed. Since 1986, 15000 changes to the tax code have been made. Despite this effort to simplify the US tax code, the words in the Internal Revenue Service (IRS) code have since doubled. Further, during the first three years after the Act was signed, 80 per cent of the Members of Congress who were most responsible for passing this bill were sponsoring legislation to undo the reform. They were doing so because it was profitable. All the narrow sectional interests wanted to undo aspects of the reform, and as a consequence federal politicians were receiving campaign contributions that were creating political pressure. The initial sense of urgency to reform the tax code had evaporated; the media turned its attention to other issues. The American tax code continues to sag under the weight of particularistic interests. 


\section{The puzzle of reform: why do some succeed while others fail?}

Why, then, is it that some reforms seem to stick while others collapse? I have applied this question to 10 canonical reform achievements in the United States and have found a striking variety of outcomes (Patashnik 2008). Some seemingly momentous reforms have left no permanent trace in governing dynamics; others have been repealed or eroded; others still have become deeply embedded in policy practice, changing the way in which subsequent officeholders of both major parties have had to deal with the issues at hand.

In my analysis, I define reform as a deliberate non-incremental change in an existing line of policy, intended to impart instrumental rationality on governmental activity to make it more rational, or to distribute benefits to some broad constituency. It is thus an effort to make government more effective, to create a more logical relationship between the policy tools that are used and the intended goals, and to ensure that government works for the broad majority instead of for the benefit of some narrow constituency. It is not about breakthrough policies where government is penetrating a previously unoccupied field for the first time where there was no government activity, but rather literally re-forming - forming again - an area where government is involved, but has not been as effective and equitable as it should be.

Indeed, in our age of the modern welfare, regulatory, administrative state, most of what government does today involves reform. There are not many areas where we have completely barren policy terrain, and this is why reform is often hardas it mainly concerns altering pre-existing public or private arrangements. As Hugh Heclo has observed, there will be inevitable resistance to change from existing stakeholders who benefit from the existing arrangements. We are not simply changing government's goals; we are trying to change the way in which actors operate in the public sector and the private sector, including businesses and other types of organisations, families, and individuals.

We must thus distinguish between two phases of reform. The first is the enactment phase, in which initial success depends on policy advocates and experts being able to develop solutions. This can be extremely difficult. We need political entrepreneurs to frame problems, introduce new policy products, and mobilise the latent sentiment for change. What is then needed is the establishment of conditions that allow rank-and-file members of a parliament to vote for the reform. Yet the tactics used to win the initial adoption of a reform do not necessarily assure its sustainability going forward. Indeed, some of the very strategies that are most useful in helping ease the adoption of a reform can themselves cause sustainability problems. Consider the following three strategies that advocates of reforms use to make the adoption of a reform possible. 


\section{Informational strategies}

This involves alerting the public that there is a problem, and thus a need for reform. This can be done by using symbols or linking the specific reform cause with a broader issue that resonates with the public. The problem with informational strategies is that they often have a short shelf life. The media might initially be useful in highlighting some pathology of government or some narrow group that is profiting at the public's expense, but the media is fickle, and might not stick with the issue after the reform is adopted. Further, it is difficult to use symbolic politics and paint with a broad brush when we enter the murky implementation phase. Advocates pushing the initial passage of a reform might be able to present it as a case of good verses bad, or it might even become a salient campaign issue for a candidate. But such use of symbolism becomes increasingly difficult when it comes to composing the detailed regulations needed to carry out the reform.

\section{Procedural strategies}

It is fundamental to frame the debate in a way that makes it hard for politicians not to vote for the reform. Consequently, policy advocates seeking to build support for the initial passage of a reform will try to create parliamentary rules that make it easy for law-makers to say yes, and make it hard for them to amend the reform or strip it away. The problem with this strategy is that after the bill has been signed into law, law-makers can submit any amendment they want. There might be a narrow interest group that pushes for an obscure provision to which no-one will pay much attention and thus it will pass, potentially undermining the original goal of the reform in question.

\section{Compensation strategies}

It is likely there will be some clientele group unhappy with a reform. A frequent enactment-phase strategy is necessary to give extra benefits or provide for transitional arrangements, to gain the group's support or at the very least to tame their opposition. The problem with this strategy is that once losers agree to accept a legislative change, if they are given compensatory benefits, what is to stop them using this precedent to demand increased benefits in the future? It might be possible to rent 'losers' in a democracy for a little while, but is it possible to buy them in perpetuity? This becomes increasingly difficult if the government is implementing a transitional scheme over a long period, promising adjustments along the way. Will losers stay 'bought' for the entirety of a transitional scheme, even if they know there is an election in between the adoption of the scheme and its final implementation date? Their acquiescence is never guaranteed. 
The second stage of reform is post enactment. Once a reform has been passed it does not mean it has been won; all that has been won is the right to fight another day. It is rare for a reform to become embedded in an instant; consolidation takes time. During this interim period, the old policy system-which was so inefficient and inequitable that it needed reforming in the first place - must be dismantled. The old system must be uprooted, and a new one constructed in its place.

Reform outcomes are never completely settled because democracy continually adapts and responds to new pressures. There is no end point. And yet, it is possible for a reform to become so deeply embedded in governance, and in the adaptations of social actors via policy feedback effects, that its subsequent reversal becomes virtually unthinkable, even if the next parliament retains the legal ability to enact another policy that would undo it. Let me now examine how we can tell when this is likely.

\section{Assessing a reform's prospects for success}

There are several ways to assess whether a reform is likely to stick or not. First, we must look for shifts in governing arrangements induced by the reform. This involves tracing the evolution of governance institutions both before and after the reform. By doing this, we can pose the following questions: are we assembling a new system of governance? Are we creating a new agency, authority, or state capacity? Are we disassembling something, or are we simply displacing its authority? And finally, are we layering? Layering, as Stephen Skowronek has pointed out, involves a reform leading to the overlapping of two authorities. It can be a problem, as both authorities inevitably have different interests, values and cultures, so will clash. While the reform might have handed responsibility to a new authority, the old reform - its stakeholders, its expertise, and its links to the media- has not yet been eliminated.

When assessing whether a reform has changed governance, further questions to ask are: does this reform have prospects that are positive going forward? How extensive or limited are these shifts; how permanent or ephemeral? How do these shifts interact with surrounding authority? And finally, will they clash with the other power centres in that arena, or will they rather reinforce and complement them?

As an example, consider the system of public management instituted in the United States by the Clinton Administration. This involved Vice-President Al Gore trying to make the American bureaucracy more customer centred and efficient through changing the way in which the US Federal Government buys goods and services from private contractors. The desire for this reform came 
about partly because the American procurement process had become extremely litigious; when private firms lost a contract bid, they would often sue. Reformers argued that the agency in question was overly friendly with the Contract Litigation Bar. They proposed keeping the authority to protest and use judicial process, but taking it out of that agency and transferring it to another one.

Layering also resulted from this reform. While a less-regulated procurement system was created, this was simply put on top of the existing civil service system. The problem with this approach was that the civil servants did not have the training, resources, capacity or the incentives to carry out the new system. In this way, the Clinton Administration changed its public policy, but it did not change the state's capacity to administer the policy in a way that was going to be as robust. By layering a high-discretion, performance-oriented purchasing system atop an understaffed civil service, traditional oversight mechanisms became focused not on good performance, but on the rooting out of fraud, waste and abuse. This approach resulted in much political tension, and ultimately failed to change the way in which Congress oversees the procurement process.

Another way of assessing a reform's sustainability potential is to look at the reactions of private social actors, of businesses, families, and citizens, because ultimately, they are they actors who generate support. Private social actors determine what government does, so it is critical to consider how private actors react to what government is trying to achieve. Recent research shows that public policies are not merely the outcomes of political forces, but can also cause politics. When a policy is robust, it can change the way in which citizens vote and change the way citizens conceive of politics. Similarly, when policies have strong feedback effects - the ability to remake alignments, remake voting patterns and remake coalitions - their very existence influences and constrains governing possibilities going forward.

For this reason, we need to identify key policy feedback mechanisms, including the extent to which reforms change (or fail to change), the identities and affiliations of constituencies, and the degree to which different constituencies make investments themselves predicated on the expectation that this new policy will continue. When we see businesses and families organising their lives around the expectation that government is going to do certain things or act in a certain way, candidates must take this into account before voting those expectations away.

Alternatively, there might be no change in the positions taken by constituency groups - or in group identities and affiliations - before and after a reform. The same groups that liked a particular policy continue to like it, and the same groups that did not like it, continue to dislike it. Further, when group investments in a policy are modest - in other words, people, businesses or families are not putting 
significant private money or resources at stake in the expectation that reforms will continue - there is a higher probability of reversal because the reform is not rooted in society. This is because nobody is organising their lives around the expectation that the reform will continue. It is this combination of fluidity in groups and a lack of significant personal investment that presents the greatest potential for reform erosion. The original reform might stay on the books, but new public policies will be continually adopted in future years that might be antithetical. Alternatively, when we see stable and extensive investments, the reform has a high probability of becoming entrenched.

The most powerful effect to consider when assessing a reform's sustainability potential is what I call reconfiguration. This occurs when the reform causes new coalitional alignments to form or new interest groups to emerge that were previously not in that policy sector and induces such actors to make long-term, hard-to-reverse commitments based on the expectation that the reform process will continue. The combination of shifts in coalitions and the stimulation of significant investments causes the whole arena to change, because these new actors are committing their own economic and organisational resources to the reform. The policy sector has been thoroughly reconfigured, making it extremely difficult for officeholders to resurrect the status quo ante bellum, even if they wished to do so. All the political pressures impinging on that sector have fundamentally changed, and it would thus not be in the government's best interest to undo its decision.

\section{Lessons in sustainable reform: two case studies from the United States}

To illustrate some of these arguments, consider two case studies from the United States. The first is the deregulation of the American airline industry in 1978. Prior to that year the government regulated the airlines in the United States; it decided where the carriers may fly and how much they may charge. The only way airlines could compete was on service. The lack of price competition rendered air travel prohibitively expensive for most Americans - hardly an ideal situation for a country as geographically vast as the United States.

Many economists made the case for airline deregulation on microeconomic grounds: if the airline market was contestable, it would become more economically efficient, and fare prices would fall. To sell deregulation to the broader public, however, its advocates used symbolism. This was the mid 1970s, an era when there was concern about the increasing role of government. Consequently, airline deregulation was sold as a way of removing the heavy hand of government from the market. Additionally, the reform was pitched to the public as a solution 
to the high inflation America was experiencing at the time- even though, in truth, most economists would acknowledge that regulation of the airlines was not a major contributor to the overall level of inflation in the United States.

Naturally, airline deregulation faced fierce opposition from powerful and well-organised groups. The major airlines had no interest in change, having practically enjoyed guaranteed profits under the previous arrangement. All the big carriers argued their case using the symbolism of a decrease in safety standards should deregulation eventuate, and many continue to seek economic rent and protection from competition to this day. The labour unions, too, opposed deregulation, as their workers had been getting high wages in a heavily regulated sector where they did not face market competition. And yet, airline deregulation passed Congress overwhelmingly - 363 to eight in the House of Representatives, and 83 to nine in the Senate.

But why has airline deregulation persisted? It is a puzzle for several reasons. First, the issues that prompted deregulation have faded. Inflation is no longer the problem in the United States. Second, the members and the coalition alignments in Congress who were responsible for enacting this policy are no longer around. Third, the deregulation did not work out as perfectly as expected, with the airline industry still plagued by problems. Planes are crowded, service is often poor, and there have been accusations of predatory pricing. Further, there are also many other well-organised losers from airline deregulation, including creditors, unions and some cities. It is certainly not the case that nobody is unhappy with this reform. And yet, despite these problems, and a frustrated public that could be mobilised on this issue, subsequent policy interventions since 1978of which there have been many-have mainly reinforced the reform path, as Michael E. Levine has observed. Carriers have retained the freedom over pricing and routes, and despite ongoing discussion of re-regulation to capture or restore rents - or even to minimise the cost of disruption - this has never eventuated.

What, then, explains the endurance of this reform? The principal factor is that airline deregulation is an example of the politics of reconfiguration. First, this policy prompted the disassembly of the governance arrangements of the old interest-group system. The agency that regulated the airlines, the Civil Aeronautics Board, was eliminated. To be sure, there are still officials in Washington who are concerned with airlines, and some of them are in favour of re-regulation. But they are concentrated in the Department of Transportation, where they lack the bureaucratic independence and autonomy to launch their initiatives. Airline policy making today is mediated by much broader and conflicting political forces than previously because of that change in governance arrangements. 
Second, the economic adaptations of social actors to airline deregulation have made the reform self-reinforcing. As Senator Jack Danforth once said, you cannot unscramble an egg. Once set in motion, these forces are not going to be reversed. Airlines and service providers have made massive investments of human and physical capital predicated on the expectation that they will get to determine where they fly. Fortress hubs have been constructed and fleets created to cater for these new management systems. All sorts of private actors have built terminals and hangars adapted to the new route structure that emerged post deregulation. It would thus be impossible to reinstate the old system without disruption. Congress still has the authority to re-regulate the airline industry, but it would be a massively disruptive move.

Next, airline deregulation has resulted in huge changes in coalitional alignments. New discount carriers have entered the market, carriers whose very existence is predicated on competition. As for the carriers that predated deregulationthe legacy carriers - they have merged, struggled to reinvent themselves, or disappeared altogether. The heterogeneity and fluidity of sectoral interest ushered in by airline deregulation have destroyed the cohesion of the old interest-group system. Previously, government faced constant pressure to maintain the system. Now the old interest group has splintered into carriers with conflicting views on whether they are in favour of regulation or re-regulation. This lack of constant uniform business pressure makes it easier for government not to do anything, because since each actor faces a different strategic situation, any attempt to reregulate is going to encounter political resistance from some quarter.

Further, there has been a shift in the internal governance of airlines as a result of deregulation. After deregulation, the internal governance structures of the airlines - for example, CEO pay, the concentration of ownership, board sizegravitated towards the governance models of unregulated firms, because they too were now unregulated. Consequently, it would now be costly for these firms to return to their previous set-ups, because they have adapted their corporate DNA to suit the post-regulation environment. Similar outcomes have occurred as a result of other American reforms. The Employee Retirement Income Security Act of 1974, for example, was enacted to regulate the way in which private corporations deliver pensions and health benefits. Consequently, American private firms adapted by setting up human-resource offices and hiring tax and pension experts to rewrite and manage their own benefit plans. There is an almost Darwinian 'natural selection' process at work here: rather than powerful actors selecting the reforms that they want, deeply embedded reforms select the organisational properties of the actors who survive.

A second major factor to explain the endurance of American airline deregulation has been its ability to survive a significant exogenous shock. The ability to do this is a key test of the sustainability of any reform. When something no-one 
foresaw rocks a policy sector — be it a scandal or some kind of disaster - will the reform stand up or will it collapse? For airline deregulation, this exogenous shock was the attacks on the United States on 11 September 2001.

Following the attacks, it was unclear whether policy makers would abandon or maintain the reform. It is highly unlikely the American Government would have undertaken airline deregulation had the 11 September attacks occurred in 1977- there simply would not have been a push to reduce the government's role in the sector. But the attacks happened 20 years after airline deregulation had become embedded. Of course, we did see policy responses in the airline sector. Flights were grounded for weeks, then severely cut back once they resumed; the Federal Government bailed out the airline sector because it was bankrupt. In addition, the Air Stabilisation Board (ASB) was created to distribute US\$15 billion in loan guarantees and cash assistance. But significantly, this new governance arrangement was given very limited authority, and it was cautioned not to slow the transition of legacy carriers to the competitive market.

Indeed, despite the personal intervention of the then Speaker of the House, Dennis Hastert from Illinois, the loan application from United Airlines was rejected three times. In other words, here we have the most powerful member of the US Congress, with significant airline interests in his district including O'Hare Airport, pleading for funding for United Airlines. Yet the ASB did not feel compelled to give it. This is a testament to the entrenchment and governance configuration capacity of airline deregulation.

By way of contrast, consider now an American reform that has not become embedded and the reasons why. 'Freedom to Farm' was an effort in the mid 1990s to scale back the huge amount of agricultural subsidies that the US Government gives its farmers. These agricultural subsidies are economically inefficient, inequitable, and flow mainly to large agribusinesses rather than the family farmers they were designed to protect. There is bipartisan agreement among experts that these farm subsidies are difficult to justify on the merits. They cause problems for developing countries, and contribute to obesity in the United States. But because farmers are popular in the public's eye, it was agreed Freedom to Farm could not be sudden, so it was designed to gradually transform the agricultural sector into a market system over five or seven years.

And yet, since Freedom to Farm was enacted in 1996, the United States has spent more - not less - on agricultural subsidies. This is because after 1996, the economic conditions in the agricultural sector took a turn for the worse, principally due to harsh weather. The powerful farming lobby returned to Washington and managed to secure extra funding, the excuse being that no-one foresaw worsening market conditions when the bill was proposed. 
From the three principal American reforms, this chapter has highlighted - tax reform, airline deregulation and Freedom to Farm - we can identify different institutional shifts. First, airline deregulation resulted in extensive shifts in governance. The Civil Aeronautics Board was eliminated, subsequent court rulings reinforced the deregulatory path and thus created a high barrier to proving predatory pricing cases, and the post 11 September bailout was conducted by a temporary board with a narrow mission. In contrast, in the taxation and agricultural sectors, the same kind of governance shifts did not eventuate. For example, there were no shifts in power in tax policy committees, and the transaction costs for creating new tax breaks and new tax barriers were not increased.

As a sidenote, one reform was layered atop the 1986 tax reform that did brieflyunintentionally - help promote the original reform's sustainability. In 1990 Congress passed a deficit-reduction act called the Budget Enforcement Act. This Act had a clause called PAYGO, according to which if government creates a new tax break that loses money, it must find replacement money from somewhere else in the budget. This was a disincentive for Congress to create new tax breaks for a couple of years. The Budget Enforcement Act lapsed, however, in the late 1990s when the US Government briefly started running budget surpluses, removing the need for a deficit-reduction act. This example demonstrates that a reform's sustainability will be affected by whatever legislation comes after it. Subsequent laws can accidentally serve to reinforce the path of the original reform — or they can undermine it.

As far as Freedom to Farm is concerned, as with the tax reform of 1986, extensive shifts in governance arrangements did not eventuate. One need only consider that the permanent law that provides the underlying authority for the Federal Government to dole out benefits was not repealed. Instead, Freedom to Farm was layered upon this law. There was a consequent shift in congressional arrangements, but it was only temporary.

The three reforms each had different policy feedback effects. In the airline deregulation case, new constituencies were built and there was a changing of coalitional alignments and the fragmentation of interest groups in a way that helped sustain the reform. In the other two cases, however, these patterns did not emerge. In the tax arena, we did not see new coalitions or the disempowerment of tax lobbyists, and in the agricultural sector, we did not see farmers being stigmatised or public opposition to the continued provision of subsidies. 


\section{Conclusion: promoting reform sustainability}

What can reform advocates do to promote reform sustainability? First, we need to anticipate sustainability problems ex ante. This can be done by using forward and backward mapping techniques. We need next to remember that reforms are typically most vulnerable during their early years, and that we need to use policy design to stimulate durable shifts in governance and group identities. We also need to be careful about front-loading costs and back-loading benefits, because these threaten our ability to build up a constituency for the reform.

We need to be strategic about the use of side payments and compensation schemes. Supporters should not simply be rented for the short term; ways must be found to reallocate power so that it becomes harder for the former beneficiaries to come back and fight another day. This is not easy, and can require complex legal arrangements.

We need to cultivate new reform-oriented clienteles - to create costs in subverting reforms by establishing new property rights. This is one reason the American Acid Rain Emission Permit Trading system has worked so well: there are new actors who have rights to emit sulfur dioxide, and they own those rights. These new actors do not want to see those rights taken away; the system has created new stakeholders.

Next, policy makers must not implement reforms without first establishing the bureaucratic capacity and the legal authority needed to make them work. This is a particular problem in the United States, because our state capacity is weak, and we have a difficult time strengthening it - for both cultural and institutional reasons. Further, reformers cannot rely on minimum winning coalitions. If a reform passes by two votes, its authors should seek a broader coalition to increase the likelihood of the reform sustaining itself even if the next couple of election results are unfavourable.

Additionally, to ensure entrenchment, reformers must invest significant organisational and financial resources in long-term reform monitoring and advocacy. They must recognise that reform consolidation is less sexy than reform adoption, and that the media cannot be relied on for continued coverage. Instead, it is up to the policy reformer to draw attention to the achievements of their reforms, and to make the public aware of the positive outcomes they are achieving.

We must unmask attempts to unravel the reform. Many efforts by narrow constituency groups and stakeholders to destroy reforms can take place in obscure bureaus and government proceedings when no-one is looking. Consequently, reformers must not think that simply because something is a third-tier venue, nothing is happening there; reforms are often eroded in back rooms. 
Next, actors who played key roles in reform adoption should be encouraged to remain involved in the issue. Usually there are a few high-ranking people who were instrumental to the reform, be they key politicians or staff. They know the most about the issue, and they have the passion. The problem is that politicians want to remain in the media limelight, but once a policy has been enacted, it will quickly lose the media spotlight. Consequently, in America at least, their attention turns to other issues. It is thus very rare to find a politician or elected official who will stay engaged with the issue, because they always want to be near the centre of power. These actors must be made to understand that their work is not done. Their leadership is needed at least to get through that first early stage of reform consolidation.

Finally, policy reform is a long-term project, and should be considered as such. Consequently, policy evaluation should occur at multiple stages, each of which should be forward looking. Progress should be judged not simply in terms of whether the reform is delivering benefits to the public at the moment, but whether the reform has reconfigured the political context in which subsequent decisions will be made.

\section{References}

Patashnik, E. M. 2008, Reforms at Risk: What happens after major policy changes are enacted, Princeton University Press, Princeton, NJ.

The New York Times, 22 October 1986, 'A Tax Law to Hail. Yes, a Tax Law'.

The Sydney Morning Herald, 24 October 1986, 'Reagan Ronald stumbles over his historic $15 \mathrm{~kg}$ tax law overhaul'. 